\title{
1. Introduction: EU citizenship, a matter of gender, generations and family dependency
}

\author{
Trudie Knijn and Manuela Naldini
}

\section{GENDER AND GENERATIONAL DIVISION IN EU CITIZENSHIP}

EU citizenship is a contested concept and a slowly developing process of creating, step by step, a level playing field for citizens of all EU Member States irrespective of their home country. The concept is contested because national, transnational and supranational rights, duties and cultural sentiments interfere with each other, and citizens as well as politicians strive for optimal results in the balance among national, transnational and supranational aspects of citizenship (De Vries and Van Waarden, 2018). EU citizenship directly relates to the basic principle of free movement and the exercise of individual citizenship rights. However, the way in which individual citizens as family members (as a spouse, partner, child, or parent) are embedded in the institutional, legal and cultural contexts, especially when moving and travelling, can make a great difference in fulfilment of their citizenship rights. Gender and intergenerational relations, care-related rights and practices, family benefits and allowances, as well as services for families, define family obligations and interdependencies. These are crucial for understanding the real possibility to exercise social and individual citizenship and what has been understood as practices of citizenship (Williams, 2004; Tronto, 2005), even more so when it concerns EU citizenship.

The relationship between citizenship and gender has largely been conceptualized by feminist scholars, some of whom have examined how (welfare) states regulate and shape the social reproduction of their citizens, and in so doing also that of the 'nation' and of 'belonging' (Lister, 1997; Yuval-Davis, 1997, 2011; Siim, 2000; Roseneil et al., 2013). Others have analysed the gendered social policies of welfare states regarding care, family relations, social assistance, childcare and elderly care (Leira, 1992; Lewis, 1992; Daly, 1994; Hobson, 1994; Lewis and Ostner, 1994; Knijn and 
Kremer, 1997; Saraceno, 1997; Naldini, 2003). This strand of scholarship emerged as criticism of male-biased mainstream theories and findings of comparative welfare state research (Esping-Andersen, 1990, 1999; see also Orloff, 1993).

A core issue in analysing gendered citizenship in welfare states, and one of the themes of this book, is care as an inclusive aspect of gendered social rights. The analysis of care and citizenship defines care as a matter of interdependent though gender-unequal social activity based on an inherent human need to receive care, and the right to give care (Knijn and Kremer, 1997; Lister, 2007). It assumes a social-liberal human condition in which individuals should be facilitated to care though not obliged to do so, while the right to receive care is an issue of general interest (common good) that is, a collective social responsibility. Studies have focused mainly on the frequently underpaid labour of caring that often goes unrecognized and yet is indispensable to human society, and on how the division of care work generates differential power relations between men and women, and children and adults. They point at gender-unequal social conditions and the social undervaluation of care work (see also Ungerson, 1990, 1997; Kittay, 1999; Folbre, 2001). In parallel to the attention to care work, scholars have focused on public and private care services as a domain of welfare states that could set women free from unpaid domestic work: childcare services and their quality and costs, elderly care facilities, home care and care for disabled people. Comparative welfare state studies conducted by intensive internationally cooperating scholars have evidenced the huge differences in services, work conditions and costs of care services in European Member States. Explanations for differentials in family and gender policies are found in both structural factors such as population ageing, economic and labour market developments, and cultural factors such as political and religious ideologies, family values and gender ideologies. Determinants have each in their own way, and in specific configurations, contributed to newly developing power resources such as women's movements resulting in silent (r)evolutions of expanding - though diverging - family policies in European Member States (Van Kersbergen, 1995; Hobson and Lindholm, 1997; Leira, Tobio and Trifiletti, 2005; Kremer, 2007; Borchorst and Siim, 2008; Van Oorschot, Opielka and Pfau-Effinger, 2008; Knijn and Saraceno, 2010; Saraceno and Keck, 2010; Morgan, 2013; Ferragina and Seeleib-Kaiser, 2015; Fleckenstein and Lee, 2014; Abe-Estevez and Naldini, 2016).

More recently, two further strands of the literature have explored the inability of young adults as newcomers on the labour market yet without social rights to 'form an independent household' (Orloff, 1993; Knijn, 2012) and who are therefore at risk of renewed family depend- 
ency (Newman, 2012), and - often female - migrant care workers as a vulnerable category of mobile workers (Ruhs and Anderson, 2010; Lutz and Palenga-Möllenbeck, 2012; Da Roit and Weicht, 2013; Cangiano, 2014).Young adults as well as migrant care workers have to deal with participatory disparity resulting from their ambiguous social position as dependent members of the family/the private home and not yet fully recognized citizens able to exercise political, social and civil rights. These research strands have been crucial for analysing gendered citizenship, but with a few exceptions (Verloo, 2005, 2007; Knijn, 2012) they shed little light on the meaning of EU citizenship in relation to the meaning of family dependency as a driver of gender and generational policies. EU citizenship is a challenge as well as a barrier for citizens of the (still) 28 Member States. It lies at the core of the EU's polity though it is contested and systematically undervalued and underused by the citizens themselves as well as by their political representatives. And, although EU citizenship guarantees economic, civil, social and political rights that extend beyond national borders, most EU citizens are not aware of their rights and do not make use of them as EU citizens (Granger, 2018). Moreover, EU citizenship is mostly work related and ignores or is unable to perform in accordance with its gender-equal principles when it comes to the domain of family-related laws and regulations, and the ensuing social rights. This book carries forward several issues and concerns expressed by a wideranging body of literature on gendered citizenship, care, and diverse family relations. It does so by focusing on the relationship among family members on horizontal (partners) and vertical (parents and children) dimensions, care, and care work from the perspective of EU citizenship.

\section{EU POLICY AND CITIZENSHIP: THE FAMILY AS A MISSING LINK}

This book highlights the extent to which EU citizenship is different for women and men, for the young and the old, for those who stay in their own country and for those who move within the European Union. It covers diverse aspects of EU citizenship ranging from the political citizenship of young Europeans, the civil and social rights of migrant care workers, reproductive rights and variations in family law among Member States, to EU gender politics and policies. Social, economic and civil citizenship rights related to gender equality and care arrangements have been high on the agenda of the EU for a long time. Because most of these EU policies have been implemented only via 'soft law' - the open method of coordination (OMC) and benchmarking, which are not free from ambiguities or 
tensions (Room, 2005; Verloo, 2005) - they are sensitive to national political agendas. More than any other social dispute they seem to be very much influenced by national, cultural and institutional path dependency, and therefore form a barrier to equalizing the status of all European citizens by EU policy.

The missing link between EU's gender equality agenda and practices in EU Member States obviously came to the fore during the recent Great Recession (GR), the financial and economic crisis resulting in austerity politics with severe consequences for newcomers on the labour market (the young), female workers in public services, and dependent elderly people (mainly women). Throughout Europe, the retrenchment of welfare states has occasioned high levels of unemployment among women and young people, with levels of 30-50 per cent of youth unemployment in southern Member States. Due to their ambivalent status as 'in-betweens' - that is, in between a dependent family member and a full worker - most of these unemployed young people had to fall back on their families as a last resort. The same happened to many fired women who were denied an individual welfare benefit because of household-based welfare benefits. The GR demonstrates the harsh effects of incomplete citizenship rights that are still work related. Intergenerational and gender dependencies reoccur due to austerity policies and in reaction to high unemployment rates, in regard to which the EU had problems in finding an adequate response (Watt and Nikolova, 2009; Puetter, 2012; see also Knijn and Yerkes, Chapter 8 in this book). During the GR, the balance among the state, the market, and the family, once called the 'welfare triangle', has returned to refamilialization, mainly hitting young people and women. It has also hit older dependent citizens, who have lost previous services, pensions and security. In periods of economic and financial crisis, the EU's policy, with its accentuation of economic goals and financial prudence, appears unable to protect the interests and social rights of its most vulnerable citizens, in particular those who can be defined as family members: the young, women, elderly people, and even migrant care workers.

In parallel, to some extent, the EU has safeguarded specific family rights that extend beyond the definition of the traditional family. It has done so via recognition of real, existent family relations with a child instead of only those that are regulated by (national) law. The European Court of Human Rights guarantees such rights. In regard to mobile EU citizens, Directive 2004/38/EC on the freedom of movement and residence includes, among family members, direct descendants under the age of 21 or persons who are dependents of the spouse or partner (see Long, Naldini and Santero, Chapter 5 in this book). In spite of these EU regulations, and due to a lack of homogeneity of family-related rights in Member States, the four 
freedoms of the European market (free movement of goods, capital, services and labour) may be compromised, in particular for young people intending to move from more liberal to still traditional countries in which diverse family forms are not recognized and care-related social rights are minimal. In combination, this EU policy with regard to family life implies that formally and in practice, family life and family relations as such are broadened in accordance with the lived experience of many EU citizens. Moreover, the family life of mobile citizens is guaranteed, which might be a factor stimulating intra-EU mobility and migration for work. However, the downside of this broadening of the definition of family relations is the increasing family dependence of unemployed partners, young adults and elderly people who have lost the protection of national welfare states. While during the past decades the legal definition of the family unit has been stretched, at the same time its caring and protective function has been expanded - the family has again become a last resort for dependent members.

\section{EU POLITICS AND CITIZENSHIP: REPRESENTATION}

It may take some imagination to relate EU political citizenship rights to gender and intergenerational relations. Nevertheless, and in addition to social and civil citizenship rights, the political arena is one of the most contested these days, and does not leave gender policies and intergenerational ties untouched. Most topical here is the increasing anti-EU sentiment of the past decade, reflected in the representation of radical-right parties (RRPs) in the European Parliament, as well as in parliaments and some governments of Member States. Most of these parties - in particular those in the Central and Eastern European (CEE) countries - support traditional family values and oppose gender equality. Some of them, in particular those in the northwestern part of the EU, protest against intraEU mobility (see Krizsán and Siim, Chapter 3 in this book). At the same time, the dominant attitude within the EU political arena is still in favour of gender equality, as represented by the Committee on Women's Rights and Gender Equality (FEMM). Tensions between these political ideologies may influence the direction of EU policies to provoke clashes either within EU polities or between the EU and some Member States. Analyses of both sides are presented in this book. The participation of young people in representative democracy seems to be declining, while their participation in alternative political activities is on the rise (see, for example, the active participation of young voters in the Brexit referendum in Helm, 2016). Effectuation of political rights as EU citizens by the future generation 
is crucial, both for achieving participatory parity and for substantiating young people's social and civil rights as potentially mobile citizens. The latter issue will be addressed in various chapters of the book. If the EU becomes more directive in the homogenization of social and civil rights, might young adults move to other Member States and what do they think about mobile social and civil rights? Also, the issue of support for representative political democracy among young adults will be addressed. In the end, it is the young that make the future, and also the future of the EU.

\section{THE AIM AND SCOPE OF THE BOOK}

The chapters of this book are largely based on a study of seven European countries considered representative of different legal, cultural and welfare state models present in the EU, namely Croatia, Denmark, Germany, Hungary, Italy, the Netherlands and Spain (in addition, the UK case is included in Chapter 7). These EU countries will be contrasted with Israel, which has specific but interesting characteristics, in order to evidence the role of EU institutions and/or their (lack of) influence on gender and generational relations - that is, on the family dimensions of citizenship.

\section{Part I: Tension Between Gender and Family Values and EU Political Discourses}

Nowadays, the European integration project seems to be experiencing its most challenging period since its creation. This is partly due to the inability of EU leaders to find solutions to a range of problems (the eurozone crisis, high levels of unemployment, the refugee crisis, etc.). During the Great Recession, this indecisiveness and the inability to find solutions may have been a weakness that engendered nationalist reactions. The UK's Brexit decision expresses this problem in an ideal-typical form, as does the rise of right-wing populist anti-European politics in most EU countries. As a result, EU citizenship has now moved from a rather special, even technical topic to the centre of the problem: under strong pressure of anti-European politics, the long-held assumption that European integration is unidirectional seems to no longer hold.

EU citizenship as such becomes a concept more contested than ever before because supra (EU) rights, duties and cultural sentiments are not always in line with national family values and political discourses. Chapter 2 by Nissen and Rolandsen Agustín shows how resistance to EU intervention in social policies, as well as the issues of 'welfare tourism' and 'welfare chauvinism', are very often untouchable matters in the political debates 
of the European Parliament. It also shows that a 'consensus built on silence' is emerging at European Parliament level on the issues of women, migrants, and ethnic, religious and minorities. The chapter shows clearly the double standards for migration and mobility as applied, on the one hand, to intra-EU mobility, which is effectively supported and promoted by the EU to develop the open European market, and, on the other, to the very restrictive policy on mobility of third-country nationals (TCNs) to protect social rights of EU citizens against an influx of non-EU migrants. The effects of that policy on migrant care workers, for example, will be outlined in Chapter 7 by Luppi, Oomkens and Gal in Part II of the book.

Adopting an intersectional (and intra-categorical) approach that problematizes the meaning and the boundaries of categories such as age, gender, ethnicity and race (Crenshaw, 1991; McCall, 2005; Yuval-Davis, 2011) evidences that, for EU citizens, the borderlines for access to social rights are constructed around employment and labour market inclusion, whereas for TCNs, ex-/inclusion depends on their legal status. Both positions have gendered effects reflected in political discourses on fundamental as well as citizenship rights. Political discourses at EU level strongly intersect with the rise of nationalism within many Member States. Chapter 3, written by Krizsán and Siim, focuses on the phenomenon of soaring nationalism, more exactly gender and family issues, which are contested and instrumentalized among most of the radical-right parties, RRPs. These instrumentalities serve nationalist, racist and populist aims, although with important variations in the justification. The intersectionality lens used in this chapter shows how nativism intersects with gender and welfare regimes. It thus contributes to strengthening articulations of an 'exclusionary intersectionality' whereby a tension between ethnic as well as family diversity and gender equality is seen as irresolvable. In that radical-right discourse, some categories of women European natives - are positioned above other groups. While some prioritize 'liberated' Western women above TCN migrant women and women from CEE Member States, others warn against gender equality as a threat to Christian values undermining the European family.

Since EU citizenship, the legitimacy of the European Union, its cohesion and prospects are obviously connected to our current and 'future' idea of citizenship, knowing what the most mobile and young category of Europeans think about EU citizenship is crucial. To this end, Chapter 4, co-authored by Dotti Sani, Knijn, Naldini, Solera and Yerkes, focuses on differences in national attitudes of European students towards the social and civil rights of men and women living in diverse family forms and the expected role of the EU in that respect. It might be not surprising that the legitimacy of the EU is high in this group of Europeans. Most students across the five EU Member States where the study was 
conducted (Denmark, Spain, Croatia, Italy and the Netherlands) have gender-egalitarian attitudes and tend to support their country's membership of the EU. They also tend to support the EU's intervention in this field. As a matter of fact, young Europeans are somewhat more in favour of an intervention at the EU level for civil rights than for social rights. As regards the convergence of rights between heterosexual and homosexual couples, however, there is a division among young Europeans living in Member States with more traditional attitudes (i.e., Italy and Croatia) and those living in less traditional ones (i.e., Denmark, the Netherlands and Spain). Young adults in the more traditional Member States show more support for EU interventions in family-related citizenship rights than do those living in countries where these rights are already fulfilled. The assumption is that young adults living in more traditional countries object to the less egalitarian legal frameworks in their countries, rendering an EU intervention more important or necessary. Furthermore, young Europeans agree that the portability of rights for mobile citizens is more important in relation to civil than social rights. They feel that citizens moving within the EU should be able to keep civil rights related to diverse family forms, adoption and reproduction. Less support is given to the notion of retaining social rights - such as housing benefits, family benefits, and parental leave - among young people living in rather generous welfare states (the Danish and the Dutch). The feeling is that the regulation of these rights is a national matter, rather than an issue to be dealt with at the EU level. Their fear might be a race to the bottom as long as a European social model guaranteeing social rights at the level of the Dutch and the Danish welfare state is a distant prospect. Obviously, differences of opinion among young EU citizens might be seen as an important indicator of the future of EU citizenship, but as shown in the second part of this book, the opinions of young adults also reflect national differentials in caring and welfare state regimes as expressed in national family policy and family law.

\section{Part II: Cross-national Balancing of Gender and Generational Rights}

Cross-national differences in political discourses and opinions on family, gender equality and migration find their expression in national social policies, migration laws, and family laws, which constitute a hard-core barrier against EU citizenship. Indeed, EU citizenship has only marginally been concerned with the rights to family life, reproductive rights and more broadly care-related rights, since they remain very much national policy matters. Part II of the book deals with some of the main issues related to family, migration and care. It seeks to shed light on convergence and divergence patterns - that is, on the frictions and contingencies between 
EU citizenship and national settings. How is the family, in its vertical dimensions (parent-child relations), defined? How are parents and children supported by the state and legally recognized by social policy and family law in different national contexts?

These are the main questions addressed by Long, Naldini and Santero in Chapter 5. On the one hand, the chapter shows cross-national variations in family policies and in family law, and, on the other, if and how the supranational, national and transnational levels intersect. Cross-national differences in family policies and family law give rise to different patterns of parents' support and recognition as a parent. Even though some similarities appear among countries in the legal recognition of different family forms and in support for the work-family balance, the crossnational differences are still significant in both family policies and family law. This chapter supports a 'polarization thesis' resembling the division in young Europeans' opinions analysed in Chapter 4. The polarization is clear-cut between more traditional countries, Croatia and Italy, with low public support for parents with children and 'prohibitionist' rules on access to parenthood, and the less traditional ones, Denmark and (to a lesser degree) the Netherlands, with higher public support and wider legal options for diverse parenthood. For the other countries included in the study a less clear-cut pattern emerges. In Spain, for instance, wider legal options to be recognized as a parent co-exist with low public support for families. The international and EU levels intersect with differences among states, showing, however, that neither a unique nor a convergent notion of parenthood exists at EU and at international level, making it difficult to see one direction of change.

Parental support policies are also discussed in Chapter 6. Halevy, Lepianka and Santero address the topic of migration, and the chapter focuses on migrants' stratified access to family reunification. In their comparison of two Member States (Italy and the Netherlands) and a contrasting country - Israel - Halevy, Lepianka and Santero show that if the 'missing link' of the family is taken into account, even though all migrants are subject to migration governance, their situations are by no means equal. While provenance appears to be the most significant axis of stratification in access to a state's territory, residential status seems more significant in determining the access to parental support policies (i.e., child benefits, parental leave, and so on). Furthermore, the analysis shows that the axis of stratification in Europe is very much guided by the principle of 'economic utility', while in the contrasting case of Israel the axis of stratification is guided by the principle of ethnic nativism. Thus, while in EU Member States the most privileged position is guaranteed to - family members of - high-skilled workers, or of more desirable categories of 
workers, in Israel, privileges are assigned to those who can prove that they belong to the defined category of ethnicity. Men and women do not circulate in the same way within the global stratification of migration, and gender is also an important dimension for explaining how citizenship rights are distributed.

In Chapter 7, Luppi, Oomkens and Gal compare three countries - Italy, Israel and the UK - in their analysis of a highly gendered category of migrants: care workers. The majority of migrant care workers are female, and they represent the contemporary precariousness of work. The analysis by Luppi et al. shows that the institutional contexts of their respective welfare states matter in understanding the variation in access to social security rights by migrant care workers in the long-term care (LTC) sector. Using a conceptual framework that combines micro-level workers' individual characteristics and institutional contexts of migration policies and social security systems, the chapter explains variation in access to social security rights of migrant care workers across the countries analysed. Besides the variation, the analysis suggests similarities in that the shared 'logic of care' (Knijn, 2000) is the common institutional denominator that explains the precariousness of migrant care work witnessed across the selected countries. In the UK, Italy and Israel, the LTC system is characterized by either a market or familial logic of care embedding LTC to a large extent in the private and/or informal sphere, and making the LTC sector an employment domain that is easy to enter for migrants. In other words, this chapter shows that, while migrant care work has increased in most EU Member States, outsourcing to the private and unregulated market or to the domestic domain of the family implies a race to the bottom in terms of employment-related social rights and the rights of mainly female care workers.

From the tendencies illustrated in the second part of the book we can conclude that EU cross-national differences are also persistent because EU citizenship so far only marginally concerns the rights to family formation, family support, reproductive rights and care worker-related rights. Despite some general lip service, some case law based on court decisions on behalf of the right to family life, and some worries expressed about the exploitation of migrant care workers, family-related issues and gender equality in the family domain remain national responsibility. As a consequence, friction between Member States' national social policy, social rights entitlements and the idea of EU citizenship emerges. The tendency to cut back public policies and publicly subsidized services in reaction to austerity politics promoted by the economic and finance-oriented EU policies define the ways in which women's position as workers (both as natives and as migrants) shape their rights and their entitlements. Thus, 
EU, or supranational attempts to harmonize family law, family and care policies, and civil and social rights conflict with several global social and economic forces (such as migration, the Great Recession, the widening of social inequalities) and global bottom-up practices (such as transnational care chains and cross-border reproductive care). The aftermath of the Great Recession, population ageing and the global stratification of migration, coupled with marketization (Brennan et al., 2012), commodification (Ungerson, 1997) and corporatization of the care sector (Yeates, 2004; Farris and Marchetti, 2017; Knijn and Lewis, 2017), contribute to the growth of precarious work, especially in LTC but also in early childhood education and care (ECEC). All this contributes to challenging the attempts to balance gender (for both native and migrant citizens) and generational rights and citizenship.

\section{Part III: Mobile and Active Youth}

From an intergenerational perspective, young Europeans embody the future EU citizen. Not only are they the most mobile category of EU citizens, they are also those assumed to encounter fewer cultural barriers because they are much more fluent in the English lingua franca than previous generations, are internationally connected via social media, and have numerous opportunities to move around Europe for higher education. The third part of this book focuses on the future generation of European citizens. There are various reasons why it is crucial to focus on young people. The first and most obvious one is that they constitute and steer the future of EU citizenship for many years to come. Second, in the aftermath of the Great Recession it is evident that access to full citizenship is increasingly problematic for young adults; they are rather vulnerable as settlers and jobseekers. Young Europeans are more likely to swell the ranks of the unemployed, suffering hardship in terms of social rights (see Seeleib-Kaiser, 2018). Together with women (as wives and as mothers), young adults make up a category of citizens most likely to be economically inactive and therefore at risk of family dependency. Even if employed, they may encounter various barriers to family formation, and very often they cannot exercise other previously acknowledged social rights, such as the right to housing, welfare benefits or work protection. In addition, representation of the interests of young people at the level of the EU appears unsatisfactory. Chapter 8 by Knijn and Yerkes considers the complexities of the relationship between EU citizenship and young Europeans, discussing EU policy centred on mobility and unemployment in critical terms. The chapter reveals the two main tensions between EU policy on youth mobility and national Member State responses. First, 
it argues that although the EU has put various programmes in place to support unemployed youth, and which have been implemented by quite a number of Member States, the results are poor. Second, at the EU level as well as that of Member States the focus is solely on employment and how it can be achieved via training and education. Acknowledgement of non-work-related social rights necessary for acquiring adult citizen status (social housing, minimum income and insured healthcare) is entirely absent. This lack of recognition of citizenship rights for young adults is illustrated by an analysis of the Youth on the Move EU programme. Third, the chapter argues that there is a major discrepancy between the EU framing of mobility as an answer to young adults' unemployment and the framing of young people's mobility in the National Reform Programmes (NRPs). In particular, CEE countries express concern about the loss of their younger generations' brains and skills.

Young people are assumed to be more mobile, though they also have reasons for not making use of the EU right to economic mobility. The reluctance of young Europeans to move is the main focus of Chapter 9 by van den Braken, Lepianka and Knijn. The chapter conducts critical discussion of existing approaches to the study of migration decision-making in order to answer the following question: why do young Europeans stay at home? In other words, the chapter's endeavour is to understand why even young Europeans do not exercise their rights to migrate for work as guaranteed to European citizens. It introduces a new theoretical framework and tests it by means of an empirical analysis using Eurobarometer data. The chapter stresses the importance of looking not only at behaviour but also at migration (or mobility) intentions. The authors conclude that noneconomic 'predictive' 'push-pull' factors are important drivers of mobility, such as discovering something new, or the political situation abroad. Better job opportunities abroad come as a less important factor. The factors most explanatory of why young Europeans do not move relate to belonging, including a social location, identification and/or emotional attachment (see Yuval-Davis, 2007).

In light of the evidence on a disconnection between young adults and politics, it is important to determine whether parties are able to mobilize and represent the segments of the public that apparently have increasingly less political voice but will be greatly affected by policy decisions in which they have not had a say. It is for this reason that in Chapter 10 Širinic and Šipić focus on young citizens and political representation. They ask whether young people identify with political parties and the extent to which political parties are successful in representing their preferences. The empirical analysis reported in the chapter finds that while young people are less likely to identify with political parties than older citizens, more than 
50 per cent of young voters still describe themselves as close to political parties. Moreover, there is no evidence to suggest that young European voters are less represented by their preferred parties than other age groups.

\section{CONCLUSION}

Has the EU contributed to more gender equality and to more equity between the generations by granting EU citizenship to all its citizens, regardless of their age, gender, family form or national background? The only way to answer this question is to determine whether men and women, the different generations, and citizens with and without work have equal access to citizenship rights. In this book we have concentrated on political rights (representation in the EU parliament and voting behaviour), civil rights (recognition of family forms and the right to reproduce) and social rights (social protection for [migrant] care workers, unemployed young people, and members of diverse families). The distinctive focus of this book on family patterns (the horizontal and vertical ones) shows that there are frictions and tensions in the dynamics of EU citizenship, and that they have increased in the recent financial and economic crises. While the EU has for several decades contributed to the legal legitimation and achievement of gender equality, and still does so with regard to diverse family forms and LGBTI civil rights, it cannot prevent the mounting antiequality sentiments and politics inspired by right-wing nationalist parties. Those parties operate within the EU parliament as well as Member States, undermining the official EU agenda. Furthermore, the gender policies of the EU itself raise increasing doubts because they focus in the end on only two aspects of gender-equal citizenship - liberal civil and economic rights - thereby neglecting the social rights of those citizens not directly connected to or involved in the mobile EU labour market. These doubts have been expressed by feminist scholars for some time, but receive increasing evidence from the reaction of the EU on the economic and financial crises. Austerity policies, cutbacks in public services, and decreasing social security have driven many people (in particular, young adults, older people and - caring or unemployed - women) back to dependence on the family. The crises have resulted in refamilialization for women and young adults, for older dependent people, and for those who take care of them.

What could be the EU agenda for regaining confidence in its status as defender or protector of all EU citizens, including those unable - or unwilling - to define themselves as footloose workers in a market that treats them as commodities that go where the work is? What can the EU mean for those who are irregularly employed, have no employment prospects 
because there is no work available, for those who have to return to their parental home at age 30, for migrant care workers without a contract, and for women who must combine a marginal job with care for their dependent parent(s)? Once the EU's ideal was to combine the most competitive knowledge economy with the European social model. In practice, the 'social model' has been undermined, resulting in frustration among large parts of the population in almost all Member States. This frustration has not only resulted in the rise of anti-European nationalist parties. It has also fuelled these parties with anti-European gender ideologies, such as their nostalgic appeal to traditional family values and masculine dominance as expressed in anti-abortion politics and homophobia. In other words, encompassing EU citizenship is not only a matter of trying to further realize social, civil and political rights of those who are so far excluded, it is also a matter of defending those rights that until now have been in the good hands of the EU.

In the introduction of Moving Beyond Barriers: Prospects for EU Citizenship? the bEUcitizen book that sets out the main results of our Seventh Framework Programme (FP7), Van Waarden and Seubert (2018) describe differences due to power asymmetries and oppression - such as class, race and gender - that should be eliminated for the sake of justice. They conclude that:

[. . .]under conditions of considerable wealth disparities and in the absence of EU-wide solidarity arrangements, the opportunities to take advantage of rights to free movement are unequally distributed. It allows the relatively well-off countries to take advantage of free-movement of labour without symmetrically bearing the costs. In a context in which economic and social spheres are decoupled, 'protection of diversity' may well mean conservation of wealth disparities and increasing inequality. Diversity might be protected wherever it does not endanger equality. However, collective action and 'harmonisation' are required when freedom and equality of European citizens is at stake. (Van Waarden and Seubert, 2018, p. 26)

This is precisely the reason this book treats gender and generational relations as of central importance. Diversity of opinions on gender, intergenerational relations, migrant workers, and young adults as full citizens can be allowed, may have nationally coloured interpretations and result in various national policy reforms as long as these do not jeopardize equality. There is not one route towards recognizing the social, economic and political rights of the young, the old, and migrant workers. However, recognizing - by payments and protection - the value of care work, social protection for those not yet able to find a secure job, guaranteeing family diversity, and most of all not seeing EU citizens only as footloose workers 
in an economic market - that is, recognizing EU citizens as citizens rather than commodities - might restore confidence in the EU as an institution to which all belong.

\section{REFERENCES}

Abe-Estevez, M. and M. Naldini (2016), 'Politics of defamilialization: A comparison of Italy, Japan, Korea and Spain', Journal of European Social Policy, 26(4) $327-43$.

Borchorst, A. and B. Siim (2008), 'Woman-friendly policies and state feminism: Theorizing Scandinavian gender equality', Feminist Theory, 9(2), 207-24.

Brennan, D., B. Cass, S. Himmelweit and M. Szebehely (2012), 'The marketisation of care: Rationales and consequences in Nordic and liberal care regimes', Journal of European Social Policy, 22(4), 377-91.

Cangiano, A. (2014), 'Elder care and migrant labor in Europe: A demographic outlook', Population and Development Review, 40(1), 131-54.

Crenshaw, K. (1991), 'Mapping the margins: Intersectionality, identity politics and violence against women of color', Stanford Law Review, 43(6), 1241-99.

Daly, M. (1994), 'Comparing welfare states: Towards a gender friendly approach', in D. Sainsbury (ed.), Gendering Welfare States, London: Sage, pp. 101-17.

Da Roit, B. and B. Weicht (2013), 'Migrant care work and care, migration and employment regimes: A fuzzy-set analysis', Journal of European Social Policy, 23, 469-86.

De Vries, S. and F. van Waarden (2018), 'Rivalling and clashing citizenship rights within the EU - Problems within the multi-dimensionality of rights', in S. Seubert, M. Hoogenboom, T. Knijn, S. de Vries and F. van Waarden (eds), Moving Beyond Barriers: Prospects for EU Citizenship, Cheltenham, UK and Northampton, MA, USA: Edward Elgar Publishing, 45-66.

Esping-Andersen, G. (1990), The Three Worlds of Welfare Capitalism, Cambridge, UK: Polity Press.

Esping-Andersen, G. (1999), Social Foundations of Postindustrial Economics, Oxford: Oxford University Press.

Farris, S.R. and S. Marchetti (2017), 'From the commodification to the corporatization of care: European perspectives and debates', Social Politics, 24(2), 109-31.

Ferragina, E. and M. Seeleib-Kaiser (2015), 'Determinants of a silent (r)evolution: Understanding the expansion of family policy in rich OECD countries', Social Politics: International Studies in Gender, State \& Society, 22(1), 1-37.

Fleckenstein, T. and S.C. Lee (2014), 'The politics of postindustrial social policy: Family policy reforms in Britain, Germany, South Korea and Sweden', Comparative Political Studies, 47(4), 601-30.

Folbre, N. (2001), The Invisible Heart: Economics and Family Values, New York: New Press.

Granger, M.-P. (2018), 'The protection of civil rights and liberties and the transformation of Union citizenship', in S. Seubert, M. Hoogenboom, T. Knijn, S. de Vries and F. van Waarden (eds), Moving Beyond Barriers: Prospects for EU Citizenship, Cheltenham, UK and Northampton, MA, USA: Edward Elgar Publishing, 178-98. 
Helm, T. (2016), 'EU referendum: Youth turnout almost twice as high as first thought', The Guardian, 10 July 2016, last accessed 6 October 2017 at https:// www.theguardian.com/politics/2016/jul/09/young-people-referendum-turnoutbrexit-twice-as-high.

Hobson, B. (1994), 'Welfare policy regimes, solo mothers, and the logics of gender', in D. Sainsbury (ed.), Gendering Welfare States, London: Sage, pp. 170-87.

Hobson, B. and M. Lindholm (1997), 'Collective identities, women's power resources, and the making of welfare states', Theory and Society, 26(4), 475-508.

Kittay, E.F. (1999), Love's Labor: Essays on Women, Equality and Dependence, London: Routledge.

Knijn, T. (2000), 'Marketization and the struggling logics of (home) care in the Netherlands', in M. Harrington Meyer (ed.), Care Work, New York: Routledge, pp. 232-48.

Knijn, T. (ed.) (2012), Work, Family Policy and the Transition to Adulthood in Europe, Basingstoke: Palgrave Macmillan.

Knijn, T. and M. Kremer (1997), 'Gender and the caring dimension of welfare states: Toward inclusive citizenship', Social Politics: International Studies in Gender, State \& Society, 4(3), 328-61.

Knijn, T. and J. Lewis (2017), 'ECEC: Childcare markets in the Netherlands and England', in B. Unger, D. van der Linde and M. Getzner (eds), Public or Private Goods? Redefining Res Publica, Cheltenham, UK and Northampton, MA, USA: Edward Elgar Publishing, pp. 150-74.

Knijn, T. and C. Saraceno (2010), 'Family law and family policy reforms in Italy and the Netherlands: Different timing, increasingly different focuses', Journal of European Social Policy, 20(5), 444-55.

Kremer, M. (2007), How Welfare States Care, Amsterdam: Amsterdam University Press.

Leira, A. (1992), Welfare States and Working Mothers: The Scandinavian Experience, Cambridge, UK: Cambridge University Press.

Leira, A., C. Tobio and R. Trifiletti (2005), 'Kinship and informal support: Care resources for the first generation of working mothers in Norway, Italy and Spain', in U. Gerhard, T. Knijn and A. Weckwert (eds), Working Mothers in Europe, Cheltenham, UK and Northampton, MA, USA: Edward Elgar Publishing, pp. 74-96.

Lewis, J. (1992), 'Gender and the development of welfare regimes', Journal of European Social Policy, 2(3), 159-73.

Lewis, J. and I. Ostner (1994), 'Gender and the evolution of European social policy', in S. Leibfried and P. Pierson (eds), ZeS Working Paper 4/94, Bremen: Centre for Social Policy Research.

Lister, R. (1997), Citizenship: Feminist Perspectives, London: Macmillan.

Lister, R. (2007), Gendering Citizenship in Western Europe, Bristol: Policy Press.

Lutz, H. and E. Palenga-Möllenbeck (2012), 'Care workers, care drain, and care chains: Reflections on care, migration, and citizenship', Social Politics: International Studies in Gender, State \& Society, 19(1), 15-37.

McCall, L. (2005), 'The complexity of intersectionality', Signs, 30(3), 1771-800.

Morgan, K.J. (2013), 'Path shifting of the welfare state electoral competition and the expansion of work-family policies in Western Europe', World Politics, 65 (1), 73-115.

Naldini, M. (2003), The Family in the Mediterranean Welfare States, London/New York: Routledge. 
Newman, K. (2012), The Accordion Family: Boomerang Kids, Anxious Parents, and the Private Toll of Global Competition, Boston, MA: Beacon Press.

Orloff, A.S. (1993), 'Gender and the social rights of citizenship: The comparative analysis of gender relations and welfare states', American Sociological Review, 58, 303-28.

Puetter, U. (2012), 'Europe's deliberative intergovernmentalism: The role of the Council and European Council in EU economic governance', Journal of European Public Policy, 19(2), 161-78.

Room, G. (2005), 'Policy benchmarking in the European Union', Policy Studies, 26(2), 117-32.

Roseneil, S., I. Crowhurst, A.C. Santos and M. Stoilova (2013), 'Reproduction and citizenship/reproducing citizens: Editorial introduction', Citizenship Studies, 17(8), 901-11.

Ruhs, M. and B. Anderson (eds) (2010), Who Needs Migrant Workers? Labour Shortages, Immigration, and Public Policy, Oxford: Oxford University Press.

Saraceno, C. (1997), 'Replay citizenship is context-specific', International Labor and Working-Class History, 52, 27-34.

Saraceno, C. and W. Keck (2010), 'Can we identify intergenerational policy regimes in Europe?', European Societies, 12(5), 657-96.

Seeleib-Kaiser, M. (2018), 'Citizenship, Europe and social rights', in S. Seubert, M. Hoogenboom, T. Knijn, S. de Vries and F. van Waarden (eds), Moving Beyond Barriers: Prospects for EU Citizenship, Cheltenham, UK and Northampton, MA, USA: Edward Elgar Publishing, 158-77.

Siim, B. (2000), Gender and Citizenship: Politics and Agency in France, Britain and Denmark, Cambridge, UK: Cambridge University Press.

Tronto, J. (2005), 'Care as the work of citizens: a modest proposal', in Friedman, M., Women and citizenship, Studies in Feminist Philosophy, Oxford, New York: Oxford University Press, 130-45.

Ungerson, C. (ed.) (1990), 'The language of care', Gender and Caring: Work and Welfare in Britain and Scandinavia, Hemel Hempstead: Harvester Wheatsheaf.

Ungerson, C. (1997), 'Social politics and the commodification of care', Social Politics: International Studies in Gender, State \& Society, 4(3), 362-81.

Van Kersbergen, K. (1995), Social Capitalism. A Study of Christian Democracy and the Welfare State, London and New York: Routledge.

Van Oorschot, W., M. Opielka and B. Pfau-Effinger (2008), Culture and the Welfare State, Cheltenham, UK and Northampton, MA, USA: Edward Elgar Publishing.

Van Waarden, F. and S. Seubert (2018), 'Introduction: Being a citizen in Europe', in S. Seubert, M. Hoogenboom, T. Knijn, S. de Vries and F. van Waarden (eds), Moving Beyond Barriers: Prospects for EU Citizenship, Cheltenham, UK and Northampton, MA, USA: Edward Elgar Publishing, 3-24.

Verloo, M. (2005), 'Displacement and empowerment: Reflections on the Council of Europe approach to gender mainstreaming and gender equality', Social Politics, 12(3), 344-66.

Verloo, M. (ed.) (2007), Multiple Meanings of Gender Equality. A Critical Frame Analysis of Gender Policies in Europe, Budapest: CEU Press.

Watt, A. and M. Nikolova (2009), 'A quantum of solace? An assessment of fiscal stimulus packages by EU Member States in response to the economic crisis', ETUI Working Paper 2009.05, last accessed 19 February 2018 at https://www.etui.org/Publications2/Working-Papers/A-quantum-of-solace-An- 
assessment-of-fiscal-stimulus-packages-by-EU-Member-States-in-response-tothe-economic-crisis.

Williams, F. (2004), Rethinking Families, London: Calouste Gulbenkian Foundation. Yeates, N. (2004), 'Global care chains', International Feminist Journal of Politics, 6, 369-91.

Yuval-Davis, N. (1997), Gender and Nation, London: Sage.

Yuval-Davis, N. (2007) 'Intersectionality, citizenship and contemporary politics of belonging', Critical Review of International Social and Political Philosophy, 10(4), 561-74.

Yuval-Davis, N. (2011), The Politics of Belonging: Intersectional Contestations, London: Sage. 